\title{
MANAJEMEN ZAKAT PASCA KEBIJAKAN PEMERINTAH TENTANG ZAKAT SEBAGAI PENGURANG PENGHASILAN KENA PAJAK
}

\author{
Oleh: Uzaifah ${ }^{1}$
}

\begin{abstract}
Abstrak
This research is taken in order to analyze the implementation of zakat and tax policy in Indonesia as well as to discuss management changes in zakah organization after a new policy regulated in 2003 was implemented. The research is a field research using the documentation, interviews, and literacy study as method to obtain data. The data then will be analyzed using descriptive and interpretative method. The subjects of the research are BAZIS of DIY Province and KPP Pratama Yogyakarta as representative zakah and tax organization based on purposive sampling method. The result shows that government policy has been applied in the Zakah Administration Organization and Tax Services Office in accordance with the regulations in the Act. Zakah management does not change after this policy compared to before it presence. Although the amount of funds collected decreases, the cause was from external factor, i.e. the splitting of the zakah administration organization in DIY into the six organizations.
\end{abstract}

Keywords: Management, Zakah, Tax, Policy.

\section{Pendahuluan}

Potensi zakat di Indonesia yang mencapai Rp19 triliun per tahun. ${ }^{2}$ Namun, zakat yang berhasil dikumpulkan hanya mencapai Rp800 juta per tahun. Faktor yang mempengaruhi pengumpulan dana zakat di Indonesia adalah tingkat kepercayaan muzakki terhadap Organisasi Pengelola Zakat (selanjutnya disingkat OPZ), pilihan muzakki untuk menyalurkan zakat langsung kepada mustahiq secara individu, kurangnya pengetahuan muzakki akan mekanisme zakat, dan kurangnya pengetahuan muzakki akan keberadaan OPZ. ${ }^{3}$

Selain beberapa faktor di atas, beban ganda umat muslim Indonesia yang harus membayar pajak juga zakat harus mendapatkan perhatian khusus dari pemerintah. Sebagai bentuk perhatian pemerintah mengenai masalah tersebut, pemerintah membuat kebijakan "Zakat sebagai Pengurang Penghasilan Kena Pajak"

${ }^{1}$ Dosen Prodi Ekonomi Islam FIAI UII, email: uza ifah@yahoo.com

2 Didin Hafidhuddin, "Baznas: Potensi Zakat Rp19 Triliun”, dikutip dari http://www.antara.co.id/arc/2009/3/2/baznas-potensi-zakat-rp19-triliun/accessed 23 Maret 2009.

${ }^{3}$ Uzaifah (2007). Studi Deskriptif Perilaku Dosen Perguruan Tinggi Islam di Yogyakarta dalam Melakukan Pembayaran Zakat. Skripsi (Tidak Dipublikasikan). Prodi Ekonomi Islam FIAI UII: Yogyakarta, hal. 91-93. 
yang dituangkan dalam Undang-undang Republik Indonesia Nomor 38 Tahun 1999 tentang Pengelolaan Zakat. Disebutkan dalam pasal 14 ayat 3 bahwa:

"Zakat yang telah dibayarkan kepada badan amil zakat atau lembaga amil zakat dikurangkan dari laba/pendapatan sisa kena pajak dari wajib pajak yang bersangkutan sesuai dengan peraturan perundang-undangan yang berlaku". ${ }^{4}$

Untuk menangani masalah pengelolaan zakat, secara khusus pemerintah membentuk OPZ yang diberi nama Badan Amil Zakat (selanjutnya disingkat BAZ). Semua hal terkait pengelolaan zakat juga di bawah intervensi pemerintah termasuk standar manajemen zakat yang digunakan guna memberikan standar pola manajemen zakat pada tiap OPZ di Indonesia. Standar manajemen zakat ini disusun oleh pemerintah yaitu oleh Departemen Agama Republik Indonesia Direktorat Jenderal Bimbingan Masyarakat Islam Direktorat Pemberdayaan Zakat pada tahun 2007. Manajemen zakat mempunyai peranan besar dalam pengelolaan zakat karena akan menentukan langkah OPZ dalam optimalisasi pengumpulan dan penyaluran zakat sehingga beban ganda yang ada di Indonesia tidak berdampak negatif pada pengumpulan dana zakat.

Manajemen yang meliputi perencanaan, pengorganisasian, pengarahan, dan pengawasan dalam penghimpunan dan penyaluran zakat di OPZ sudah selayaknya lebih tertata dengan baik. Perencanaan yang matang, pengorganisasian yang tepat, pengarahan yang serius, dan pengawasan yang maksimal adalah idealitas manajemen zakat.

Namun, di Indonesia, pelaksanaan sistem manajemen zakat belum berjalan dengan maksimal. Tidak maksimalnya pelaksanaan sistem tersebut dipengaruhi oleh beberapa faktor, antara lain: keterbatasan sumber daya manusia dan informasi yang belum terdistribusi secara maksimal baik kepada muzakki, mustahiq, maupun amil. Dengan sudah dibuatnya standardisasi manajemen zakat, diharapkan OPZ akan meningkatkan kualitas pengelolaan zakat sehingga berdampak positif guna optimalisasi peran zakat. Begitupula dengan adanya kebijakan "Zakat sebagai Pengurang Penghasilan Kena Pajak" diharapkan dapat mendukung manajemen zakat dalam menjalankan fungsinya mengelola zakat di OPZ.

Penelitian ini dilakukan di Kantor Pelayanan Pajak (selanjutnya disingkat KPP) dan OPZ di Daerah Istimewa Yogyakarta (selanjutnya disingkat DIY). KPP dalam penelitian ini dapat digunakan sebagai salah satu sumber informasi aplikasi kebijakan pemerintah yang merupakan obyek dalam penelitian ini. Sedangkan OPZ merupakan sumber informasi untuk menjawab permasalahan lain dalam penelitian ini, yaitu mengenai manajemen zakat di dalamnya. Adapun KPP yang dimaksud adalah KPP Pratama Yogyakarta dan Badan Amil zakat Infak Shadaqah (selanjutnya disingkat Bazis) Provinsi DIY sebagai perwakilan BAZ DIY.

${ }^{4}$ Undang-undang Republik Indonesia Nomor 38 Tahun 1999 tentang Pengelolaan Zakat pasa 14 ayat 3 . 
KPP Pratama Yogyakarta merupakan kantor pelayanan pajak yang bertanggung jawab langsung kepada kepala kantor pelayanan pajak wilayah DIY. Adapun tugas dapi KPP Pratama adalah melaksanakan penyuluhan, pelayanan, dan pengawasan Wajib Pajak di bidang Pajak Penghasilan, Pajak Pertambahan Nilai, Pajak Penjualan atas Barang Mewah, Pajak Tidak Langsung Lainnya, Pajak Bumi dan Bangunan serta Bea Perolehan Hak atas Tanah dan Bangunan dalam wilayah wewenangnya berdasarkan peraturan perundang-undangan yang berlaku. ${ }^{5}$

Bazis Propinsi DIY merupakan BAZ yang mengelola zakat tingkat provinsi Yogyakarta. Bazis Propinsi DIY pada mulanya berawal dari adanya pembentukan Bazis Departemen Agama yang didasarkan pada keputusan kepala Kanwil Depag DIY No. 25/KPTS/1989 tertanggal 1 Mei 1989. Tertanggal 15 Juni 1992 BAZIS Depag dikukuhkan menjadi Bazis Propinsi DIY berdasarkan keputusan Gubernur Kepala DIY No. 9/KPTS/1992 sampai dengan sekarang.

Penelitian ini bertujuan untuk mendiskripsikan aplikasi kebijakan "Zakat sebagai Pengurang Penghasilan Kena Pajak" di Bazis Propinsi DIY dan KPP Pratama Yogyakarta sekaligus untuk melihat dan mendiskripsikan manajemen zakat pasca Kebijakan "Zakat sebagai Pengurang Penghasilan Kena Pajak" pada Manajemen Zakat Bazis Propinsi DIY.

Penelitian ini merupakan penelitian lapangan (field reaserch) yang bersifat deskriptif interpretative dengan menggunakan desain penelitian kuantitatif. Subjek penelitian Bazis Provinsi DIY dan KPP Pratama Yogyakarta, sedangkan obyek penelitian adalah Manajemen Zakat dan kebijakan "Zakat sebagai Pengurang Penghasilan Kena Pajak".

Manajemen dalam penelitian ini merupakan proses merencanakan dan mengambil keputusan, mengorganisasikan, memimpin dan mengendalikan sumberdaya manusia, fisik dan informasi guna mencapai sasaran organisasi dengan cara yang efektif dan efisien. ${ }^{6}$ Sedangkan manajemen zakat adalah proses kegiatan melalui kerjasama orang lain dalam rangka pendayagunaan zakat sebagai pilar kekuatan ekonomi dan sarana peningkatan kesejahteraan umat Islam. ${ }^{7}$ Kaitannya dengan kebijakan, kebijakan "Zakat sebagai Pengurang Penghasilan Kena Pajak" adalah kebijakan yang mengakui zakat yang telah dibayarkan kepada Badan Amil Zakat atau Lembaga Amil Zakat untuk

5 Peraturan Menteri Keuangan Republik Indonesia Nomor 132/Pmk.01/2006 tentang Organisasi dan Tata Kerja Instansi Vertikal Direktorat Jenderal Pajak Menteri Keuangan Republik Indonesia.

${ }^{6}$ Ensiklopedi Ekonomi dan Perbankan Syariah, Habib Nazir dan Muhammad Nasahuddin, (Bandung: Kafa Publishing, 2008), hal. 415, oleh Griffin.

7 Departemen Agama RI Direktorat Jenderal Bimbingan Masyarakat Islam Direktorat Pemberdayaan Zakat, Standarisasi Manajemen Zakat, (Jakarta: -, 2007), hal. 19. 
dikurangkan dari laba/pendapatan sisa kena pajak dari wajib pajak yang bersangkutan sesuai dengan peraturan perundang-undangan yang berlaku. ${ }^{8}$

Penelitian ini dilakukan di DIY dengan fokus tempat penelitian adalah pada OPZ di DIY yang akan diwakili oleh Bazis Provinsi DIY dan KPP Pratama Yogyakarta. Populasi dalam penelitian ini bersifat terbatas, karena diketahui jumlah OPZ di DIY dan memiliki sifat yang homogen, yaitu merupakan organisasi yang berfungsi mengelola dana zakat. Populasi penelitian adalah OPZ dan KPP di DIY. Sedangkan sampel yang digunakan adalah Bazis Provinsi DIY, dan KPP Pratama Yogyakarta dengan teknik pengambilan sampel yang digunakan adalah purposive sampling.

Penelitian ini menggunakan data primer dan sekunder. Data primer berupa dokumentasi terkait yang dimiliki oleh subjek penelitian berupa pola manajemen zakat di OPZ dan teknis aplikasi kebijakan di KPP dan OPZ, antara lain formulir STP, bukti pembayaran zakat, dan pedoman pengelolaan zakat. Selain itu, data dilengkapi pula dengan hasil wawancara. Wawancara dilakukan dengan pengurus harian Bazis Provinsi DIY dan KPP Pratama Yogyakarta wawancara dilakukan dengan Seksi Pelayanan yang bertugas melakukan penyuluhan pajak. Proses wawancara ini dilakukan untuk mendapatkan data aplikasi kebijakan "Zakat sebagai Pengurang Penghasilan Kena Pajak" di KPP Pratama Yogyakarta dan Bazis Provinsi DIY dan manajemen pengumpulan dan penyaluran zakat di Bazis Provinsi DIY. Dan data sekunder berupa berbagai macam pustaka yang relevan dengan penelitian. ${ }^{9}$

\section{Zakat Dan Pajak Menurut Tinjauan Islam}

Zakat secara bahasa merupakan kata dasar (masdat) dari zakā yang berarti berkah, tumbuh, bersih, dan baik. ${ }^{10}$ Dari segi istilah fikih berarti "Sejumlah harta tertentu yang diwajibkan Allah SWT. diserahkan kepada orang yang berhak". ${ }^{11}$

Firman Allah SWT.

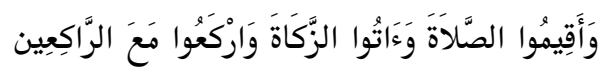

"Dan dirikanlah salat, tunaikanlah zakat dan rukuklah beserta orang yang rukuk." $" 2$

Rochmat Soemitro, mendefinisikan pajak sebagai:

${ }^{8}$ Undang-undang Republik Indonesia Nomor 38 Tahun 1999 tentang Pengelolaan Zakat pasa 14 ayat 3 .

${ }^{9}$ Muhammad Hariwijaya dan Bisri M. Djaelani, Teknik Menulis Skripsi \& Thesis, (Yogyakarta: Zenith Publisher, 2006), hal. 44.

${ }^{10} \mathrm{Mu}$ 'jam Wasith, diedit dalam Yusuf Qardhawi, Fiqhuz-zakat, alih bahasa Salman Harun dkk., (Jakarta: PT. Pustaka Litera AntarNusa, 2006), hal. 34.

${ }^{11}$ Yusuf Qardhawi, Fiqhuz-zakat, alih bahasa Salman Harun dkk., (Jakarta: PT. Pustaka Litera AntarNusa, 2006), hal. 34.

${ }^{12}$ QS.Al-Baqarah (2): 43 
Peralihan kekayaan dari sektor swasta ke sektor publik berdasarkan Undang-undang yang dapat dipaksakan dengan tidak mendapat imbalan yang secara langsung dapat ditujukan, yang digunakan untuk membiayai pengeluaran umum dan yang diguakan sebagai alat pendorong, penghambat atau pencegah, untuk mencapai tujuan yang ada di luar bidang keuangan. ${ }^{13}$

Yusuf Qardhawi, mendefinisikan bahwa pajak sebagai:

Kewajiban yang ditetapkan terhadap wajib pajak, yang harus disetorkan kepada Negara sesuai dengan ketentuan, tanpa mendapat prestasi kembali dari Negara, dan hasilnya untuk membiayai pengeluaran-pengeluaran umum di satu pihak dan untuk merealisasi sebagian tujuan ekonomi, sosial, politik, dan tujuan-tujuan lain yang ingin dicapai oleh Negara. ${ }^{14}$

Secara etimologis, pajak dalam bahasa Arab disebut dengan istilah daribah ${ }^{15}$ yang artinya mewajibkan, menetapkan, memukul, menerangkan atau membebankan, dan lain-lain. ${ }^{16}$ Ia disebut beban karena merupakan kewajiban tambahan atas harta setelah zakat. ${ }^{17}$ Jadi, daribah adalah harta yang dipungut secara wajib oleh Negara untuk selain jizyah dan kharaj, sekalipun keduanya secara awam bisa dikategorikan daribah. ${ }^{18}$

Tabel 2.1 Perbedaan Daribah, Jizyah, dan Kharaj

\begin{tabular}{|c|c|c|}
\hline Nama/Sebutan & Objek & Subjek \\
\hline Pajak (Daribah) & Harta selain Zakat & Kaum Muslim \\
\hline Jizyah & Jiwa (an-Nafs) & Non Muslim \\
\hline Kharaj & Tanah Taklukan & Non Muslim \\
\hline
\end{tabular}

Sumber: Gusfahmi, Pajak menurut Syariah, (Jakarta: PT. RajaGrafindo Persada, 2007), hal. 27.

Ada beberapa landasan teori yang dijadikan dasar pemungutan pajak oleh pemerintah, namun berbeda antara pajak non-muslim dan pajak muslim. Dalam pajak non-muslim, landasan teori yang digunakan adalah teori kekuasaan dan teori perjanjian. Dalam teori kekuasaan, pajak diibaratkan sebagai upeti dari rakyat kepada

13 Rochmat Soemitro, "Pengantar Singkat Hukum Pajak", diedit dalam Gusfahmi, Pajak menurut Syariah, (Jakarta: PT. RajaGrafindo Persada, 2007), hal. 25.

${ }^{14}$ Yusuf Qardhawi, Fiqhuz-zakat, alih bahasa Salman Harun dkk., (Jakarta: PT. Pustaka Litera AntarNusa, 2006), hal. 998.

15 Gazy Inayah, "Al-Iqtiṣad al-Islami az-Zakāh wa ad-ḍaribah: Dirasah Muqaranah, Teori Komprehensif tentang Zakat dan Pajak", dan Yusuf Qardhawi, "Fiqhuz-Zakat", diedit dalam Gusfahmi, Pajak menurut Syariah, (Jakarta: PT. RajaGrafindo Persada, 2007), hal. 27.

${ }^{16}$ Kamus Al-Munawwir, A. W. Munawwir (Surabaya: Pustaka Progressif, 2002), hal. 815.

${ }^{17}$ Gusfahmi, Pajak menurut Syariah, (Jakarta: PT. RajaGrafindo Persada, 2007), hal. 27.

${ }_{18}$ Qadhi an-Nabhani, "Nìzām al-Iqtiṣādi fi al-Isläm", diedit dalam Yahya Abdurrahman, daribah (Pajak) dikutip dari http://Hayatulislam.netlaccessed 28 Juni 2009. 
pemimpin Negara. Sedangkan teori perjanjian merupakan teori yang muncul dari pemberontakan rakyat akan sistem upeti hingga dibuat perjanjian kontra prestasi pajak antara pemerintah dan rakyat. ${ }^{19}$

Kebanyakan para ahli fikih ${ }^{20}$ berpendapat bahwa zakat adalah satu-satunya kewajiban atas harta. ${ }^{21}$ Namun, golongan lainnya sejak zaman sahabat sampai masa tabi'in berpendapat bahwa dalam harta kekayaan ada kewajiban selain zakat. ${ }^{22}$ Sekarang timbul pertanyaan apakah zakat itu sebagai pungutan biasa atau hanya sebagai kewajiban yang dibebankan kepada orang-orang muslim saja. Beberapa ahli ekonomi Islam menganggap zakat merupakan sejenis pajak karena memenuhi beberapa persyaratan perpajakan, yaitu: pembayaran yang diwajibkan, tidak ada balasan atau imbalan, diwajibkan kepada seluruh masyarakat suatu negara. ${ }^{23}$ Zakat hanya memenuhi persyaratan pertama dan kedua karena hanya dikenakan kepada orang muslim yang sudah memenuhi syarat. Oleh karena itu, zakat bukanlah pajak dalam arti yang sebenarnya. ${ }^{24}$

Apabila diperhatikan lebih mendalam, sesungguhnya zakat itu jauh berbeda dengan pajak, namun perbedaannya berbeda dengan yang digambarkan oleh tokohtokoh sekuler yang menganggap pajak adalah kewajiban kenegaraan dan zakat sebagai kewajiban keagamaan (secularism). ${ }^{25}$ Berikut beberapa perbedaan dasar antara zakat dan pajak:

Tabel 2.2 Perbedaan Zakat dan Pajak

\begin{tabular}{|c|l|l|l|}
\hline No. & \multicolumn{1}{|c|}{ Pembeda } & \multicolumn{1}{|c|}{ Zakat } & \multicolumn{1}{c|}{ Pajak } \\
\hline 1. & Arti & $\begin{array}{l}\text { Bersih, suci, berkah, tumbuh, } \\
\text { maslahat, berkembang. }\end{array}$ & $\begin{array}{l}\text { Al- daribah: Beban. } \\
\text { Jizyah: Pajak tanah \& upeti }\end{array}$ \\
\hline 2. & Dasar Hukum & Al-Qur'an dan Hadist & Ketentuan pemerintah \\
\hline 3. & $\begin{array}{l}\text { Kewajiban } \\
\text { Pelaksanaan }\end{array}$ & $\begin{array}{l}\text { Mutlak dan wajib hukumnya } \\
\text { sepanjang masa. }\end{array}$ & $\begin{array}{l}\text { Wajib bagi warga negara selama } \\
\text { berlakunya ketentuan. }\end{array}$ \\
\hline 4. & Nisab \& Kadar & Ditentukan oleh Allah SWT. & Ditentukan pemerintah. \\
\hline 5. & Sasaran & Mustahiq Aeluruh sektor kehidupan. \\
\hline \multicolumn{2}{|c|}{ Sumber: Moch. Arief, "Antara zakat dan Pajak", dikutip dari } \\
http://dsniamanah.or.id/web/content/view/110/1/accessed 26 Mei 2009.
\end{tabular}

${ }^{19}$ Gusfahmi, Pajak menurut Syariah, (Jakarta: PT. RajaGrafindo Persada, 2007), hal. 195-197

${ }^{20}$ Al-Bahr, jilid 2, diedit dalam Mu’jam Wasiț, jus 1, diedit dalam Yusuf Qardhawi, Fiqhuzzakat, alih bahasa Salman Harun dkk., (Jakarta: PT. Pustaka Litera AntarNusa, 2006), hal. 968.

${ }^{21}$ Yusuf Qardhawi, Fighuz., hal. 968.

${ }^{22}$ Pendapat tersebut datang dari Umar, Ali, Abu Dzar, Aisyah, Ibnu Umar, Abu Hurairah, Hasan bin Ali dan Fatimah binti Qais dari kalangan sahabat ra. Pendapat ini disahkan oleh Sya'bi, Mujahid, Thawus, 'Atha dan lain-lain dari kalangan tabi'in, dalam Mu'jam Wasith, jus 1, diedit dalam Yusuf Qardhawi, Fiqhuz-zakat, alih bahasa Salman Harun dkk., (Jakarta: PT. Pustaka Litera AntarNusa, 2006), hal. 973.

${ }^{23}$ Afzalur Rahman, Economic Doctrines of Islam, alih bahasa Nastangin Suroyo, (Yogyakarta: PT Dana Bhakti Wakaf, 1996), hal. 242.

${ }^{24}$ Ibid., hal. 242.

${ }^{25}$ Gusfahmi, Pajak menurut Syariah, (Jakarta: PT. RajaGrafindo Persada, 2007), hal. 216. 
Uzaifah: Manajemen Zakat...

Seperti telah dipaparkan sebelumnya, bahwa pemerintah harus berperan dalan pengelolaan zakat. Menurut Ibnu Khaldun, Negara adalah lembaga penjamin diberlakukannya syariah dan fasilitator pembangunan manusia dan kesejahteraan. ${ }^{26}$

Firman Allah SWT.:

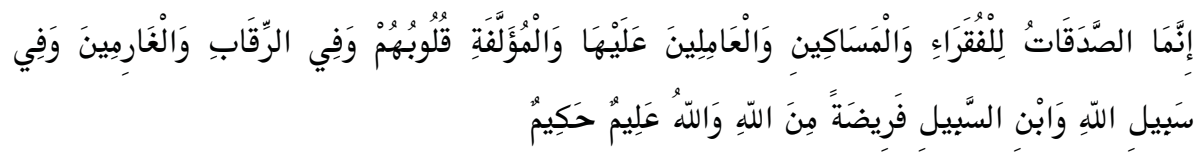

"Sesungguhnya zakat-zakat itu hanyalah untuk orang fakir, orang-orang miskin, pengurus-pengurus zakat, para muallaf yang dibujuk hatinya, untuk (memerdekakan) budak, orang-orang yang berhutang, untuk jalan Allah, dan orang-orang yang sedang dalam perjalanan, sebagai suatu ketetapan yang diwajibkan Allah, dan Allah Maha Mengetahui lagi Maha Bijaksana. ${ }^{\text {"27 }}$

Islam telah menjadikan zakat bukan hanya sebagai sumbangan wajib saja, tetapi sebagai suatu lembaga Negara yang harus dikumpulkan dan didistribusikan oleh Negara. Dengan jelas al-Qur'an menyatakan bahwa institusi zakat harus dibentuk, diorganisasikan, dan dipelihara oleh pemegang kekuasaan. Firman Allah SWT.:

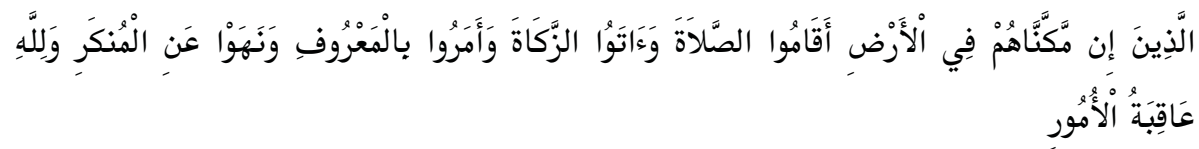

"(Yaitu) orang yang jika Kami tegubkan kedudukan mereka di muka bumi niscaya mereka mendirikan sembahyang dan menunaikan zakat. ${ }^{\text {28 }}$

Dalam urusan pengelolaan zakat, pemerintah dapat berperan sebagai: ${ }^{29}$

a. Regulator. Membuat peraturan dan petunjuk pelaksanaan pengelolaan zakat sebagai penjabaran ketentuan syariah maupun Undang-undang.

b. Motivator. Melakukan sosialisasi dan orientasi baik secara langsung maupun melalui kerjasama dengan berbagai pihak terkait.

c. Fasilitator. Mempersiapkan berbagai fasilitas penunjang operasional pengelolaan zakat baik perangkat lunak maupun perangkat keras.

d. Koordinator. Mengkoordinasikan semua OPZ di semua tingkatan sekaligus memantau dan mengawasi.

${ }^{26}$ Ibid., hal. 34.

${ }^{27}$ QS. At-Taubah (9): 60.

${ }^{28}$ QS. Al-Hajj (22): 41.

29 Departemen Agama RI Direktorat Jenderal Bimbingan Masyarakat Islam Direktorat Pemberdayaan Zakat, Standarisasi Manajemen Zakat, (Jakarta: tnp., 2007), hal. 47. 
Menjalankan fungsi regulator, sebagai petunjuk pelaksanaan pengelolaan zakat, pemerintah membuat Undang-undang Republik Indonesia Nomor 38 Tahun 1999 tentang Pengelolaan Zakat. Undang-undang tersebut juga memberikan solusi terhadap dualisme kewajiban muzakki di Indonesia yaitu kewajiban membayar zakat dan pajak. Kebijakan tersebut tertuang dalam Undang-undang Republik Indonesia Nomor 38 Tahun 1999 tentang Pengelolaan Zakat yang terdapat dalam pasal 14, yang berbunyi:

Zakat yang telah dibayarkan kepada badan amil zakat atau lembaga amil zakat dikurangkan dari laba/pendapatan sisa kena pajak dari wajib pajak yang bersangkutan sesuai dengan peraturan perundang-undangan yang berlaku.

Pada penjelasan pasal 14 ayat 3 Undang-undang Republik Indonesia Nomor 38 Tahun 1999 dinyatakan:

Pengurangan Zakat dari laba/pendapatan sisa kena pajak dimaksudkan agar wajib pajak tidak terkena beban ganda, yakni kewajiban membayar zakat dan pajak. Kesadaran membayar zakat dapat memacu kesadaran membayar pajak.

Peraturan ini didukung oleh sistem pajak yang ada, seperti yang tertuang pada pasal 4 ayat (3) huruf a.1. dalam Undang-undang Republik Indonesia Nomor 36 Tahun 2008 tentang Perubahan Keempat atas Undang-Undang Nomor 7 Tahun 1983 tentang Pajak Penghasilan yang berbunyi:

Yang dikecualikan dari objek pajak adalah: bantuan atau sumbangan, termasuk zakat yang diterima oleh badan amil zakat atau lembaga amil zakat yang dibentuk atau disahkan oleh pemerintah dan yang diterima oleh penerima zakat yang berhak atau sumbangan keagamaan yang sifatnya wajib bagi pemeluk agama yang diakui di Indonesia, yang diterima oleh lembaga keagamaan yang dibentuk atau disahkan oleh pemerintah dan yang diterima oleh penerima sumbangan yang berhak, yang ketentuannya diatur dengan atau berdasarkan Peraturan Pemerintah.

Kebijakan tersebut diatur dalam Keputusan Direktur Jendral Pajak dengan Nomor KEP-163/PJ/2003 mengenai Perlakuan Zakat atas Penghasilan dalam Penghitungan Penghasilan Kena Pajak Pajak Penghasilan.

Sesuai dengan Undang-undang Republik Indonesia Nomor 36 Tahun 2008 tentang Pajak Penghasilan dan Undang-undang Republik Indonesia Nomor 38 Tahun 1999 tentang Pengelolaan Zakat, maka berikut ilustrasi format pengenaan pajak dan zakat atas orang pribadi:

Tabel 2.3 Ilustrasi Format Pengenaan Pajak dan Zakat atas Orang Pribadi

\begin{tabular}{|l|l|l|}
\hline Gaji satu bulan & & Rp. XXX \\
\hline Tunjangan-tunjangan & Rp. XXX & \\
\hline Jaminan-jaminan & $\underline{\text { Rp. XXX }}$ & \\
\hline Penghasilan Bruto (PB) & & Rp. XXX \\
\hline Pengurang: & & \\
\hline
\end{tabular}




\begin{tabular}{|l|l|l|}
\hline Zakat 2,5\% x PB & Rp. XXX & \\
\hline Biaya jabatan 5\% x PB & Rp. XXX & \\
\hline Iuran-iuran & Rp. XXX & \\
\hline Penghasilan neto sebulan (PNS) & & $\underline{\text { Rp. XXX (-) }}$ \\
\hline Penghasian neto setahun 12 x PNS & & Rp. XXX \\
\hline PTKP (minus K/3) & & Rp. XXX \\
\hline Wajib pajak pendiri & Rp. XXX & \\
\hline Status kawin & Rp. XXX & \\
\hline Tanggungan & Rp. XXX (+) & \\
\hline & & $\underline{\text { Rp. XXX }(+)}$ \\
\hline Penghasilan Kena Pajak & & Rp. XXX \\
\hline Tarif Pajak x Rp & & Rp. XXX \\
\hline
\end{tabular}

Sumber: Gustian, dkk., Pelaporan Zakat Pengurang Pajak Penghasilan, (Jakarta: PT. RajaGrafindo Persada, 2006), hal. 282-283.

Dengan demikian, dapat diambil kesimpulan bahwa dengan adanya pemerintah menerbitkan Undang-undang Republik Indonesia Nomor 38 Tahun 1999 tentang Pengelolaan Zakat dan Undang-undang Republik Indonesia Nomor 36 Tahun 2008 tentang Pajak Penghasilan itu sudah dapat mengakomodir kebutuhan umat Islam untuk membayar zakat dan pajak. Dalam hal ini karena $\mathrm{PPh}$ memperlakukan zakat sebagai biaya, maka yang boleh dikeluarkan hanya zakat yang benar-benar telah dikeluarkan secara kas. ${ }^{30}$

\section{Manajemen Organisasi Pengelola Zakat}

Dalam mendukung upaya penyempurnaan sistem pengelolaan zakat, maka pemerintah membuat Undang-undang Republik Indonesia Nomor 38 Tahun 1999 tentang Pengelolaan Zakat. Di dalam Undang-undang tersebut, disebutkan bahwa pengelolaan zakat adalah kegiatan perencanaan, pengorganisasian, pelaksanaan, dan pengawasan terhadap pengumpulan dan pendistribusian serta pendayagunaan zakat. ${ }^{31}$

Organisasi pengelola zakat dibagi menjadi dua, yaitu:

a. Badan Amil Zakat (BAZ)

BAZ adalah OPZ yang dibentuk oleh pemerintah. Hubungan kerja BAZ di semua tingkatan bersifat koordinatif, konsultatif, dan informatif. Pengurus BAZ terdiri dari unsur pemerintah dan masyarakat yang memenuhi persyaratan tertentu. BAZ terdiri atas unsur pertimbangan, pengawas, dan pelaksana.

b. Lembaga Amil Zakat (LAZ)

30 Departemen Agama RI Direktorat Jenderal Bimbingan Masyarakat Islam Direktorat Pemberdayaan Zakat, Standarisasi Manajemen Zakat, (Jakarta: tnp., 2007), hal. 50.

${ }^{31}$ Undang-Undang Republik Indonesia Nomor 38 Tahun 1999 tentang Pengelolaan Zakat, BAB I Pasal 1 Ayat (1). 
Uzaifah: Manajemen Zakat...

Pengelolaan zakat dilakukan secara konseptual. Berdasarkan pengertiannya, manajemen adalah proses kegiatan melalui kerjasama orang lain dalam rangka mencapai tujuan tertentu. ${ }^{32}$

Manajemen memiliki dua model, yaitu: ${ }^{33}$

a. Manajemen by Result (MBR)

Adalah gaya manajemen yang menekankan pada hasil.

b. Manajemen by Process (MBP)

Adalah gaya manajemen yang menekankan pada pentingnya penataan proses dan berorientasi pada jangka panjang.

MBP amat tepat digunakan oleh OPZ. Karakter dasar MBP sangat tepat karena bisa memberi kesempatan pada semua pihak untuk berpartisipasi, dimana kualitas amil dan mustahiq ditingkatkan, dan tidak ada pihak manapun yang dirugikan.

Firman Allah SWT.:

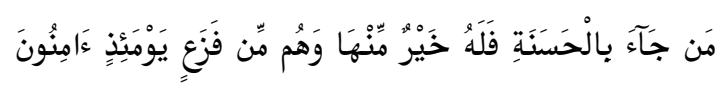

"Barang siapa membawa kebaikan, maka dia memperoleh (balasan) yang lebih baik daripadanya, sedang mereka merasa aman dari kejutan (yang dahsyat) pada hari itu." 34

Dengan prinsip itu, Islam mengenalkan karakter manajemen halal dan thayib. Melalui karakter tersebut lahir dua hal ciri penting dalam manajemen halal dan thayib, yakni menekankan pada proses dan berorientasi pada penyuburan kebajikan. ${ }^{35}$ Berhasilnya suatu usaha bukan ditentukan oleh tujuan semata tetapi karena adanya tool of management, yaitu: ${ }^{36}$

a. Man, yaitu tenaga kerja atau sumber daya manusia.

b. Money, yaitu uang yang digunakan untuk mencapai tujuan.

c. Methode, yaitu cara guna mencapai tujuan.

d. Materials, yaitu bahan-bahan yang dipakai guna mencapai tujuan.

e. Maechinedlis, yaitu peralatan yang diperlukan.

f. Market, yaitu pasar tempat kemana produk dijual. Dalam manajemen zakat, pasar yang dimaksud adalah muzakki sebagai penyetor dana zakat.

32 Departemen Agama RI Direktorat Jenderal Bimbingan Masyarakat Islam Direktorat Pemberdayaan Zakat, Standarisasi Manajemen Zakat, (Jakarta: tnp., 2007), hal. 19.

${ }^{33}$ Eri Sudewo, Manajemen Zakat: Tinggalkan 15 Tradisi, Terapkan 4 Prinsip Dasar, (Jakarta: Institute Manajemen Zakat, 2004), hal. 54-56.

${ }^{34}$ QS. An-Naml (27): 89.

${ }^{35}$ Eri Sudewo, Manajemen., hal. 77.

36 Departemen Agama RI Direktorat Jenderal Bimbingan Masyarakat Islam Direktorat Pemberdayaan Zakat, Standarisasi Manajemen Zakat, (Jakarta: tnp., 2007), hal. 20. 
Eri Sudewo membagi manajemen pengumpulan zakat menjadi dua, yaitu manajemen penggalangan dana dan layanan donatur. Manajemen penggalangan dana yang dimaksud adalah: ${ }^{37}$

a. Kampanye. Proses kampanye adalah proses membangkitkan kesadaran pembayaran zakat.

b. Kerjasama Program. Kerjasama bisa dilakukan dengan lembaga atau perusahaan lain yang berbentuk aktivitas fundrising.

c. Seminar dan diskusi. Dalam sosialisasi zakat, galang dana juga dapat melakukan kegiatan seminar atau diskusi dengan tema yang relevan dengan kegiatan dan kiprah organisasi pengelola zakat.

d. Pemanfaatan Rekening Bank. Bermaksud memberikan kemudaham donatur menyalurkan dana.

Sedangkan manajemen layan donatur yang dapat dilakukan antara lain: ${ }^{38}$

a. Melakukan pendataan donatur dengan sistem dokumentasi yang rapi.

b. Menerima keluhan donatur dan masyarakat luas.

c. Follow up keluhan-keluhan yang ada.

Senada dengan yang disampaikan Eri Sudewo, kampanye menjadi salah satu bagian manajemen pengumpulan dana zakat. Langkah-langkah kampanye yang dapat dilakukan antara lain dengan melakukan sosialisasi melalui: ${ }^{39}$

a. Media massa

b. Film dan Video

c. Leaflet/brosur/booklet

d. Portal website

e. Billboard/banner/baliho/spanduk

f. Khutbah Jum'at

g. Orientasi pengurus lembaga pengelola zakat

h. Gerakan sadar zakat

i. Desa binaan zakat

Manajemen zakat harus secara profesional guna mencapai tujuan pengumpulan dan pendistribusian zakat oleh OPZ. Strategi yang dimaksud adalah: ${ }^{40}$

\section{a. Strategi Pengumpulan}

1) Pembentukan Unit Pengumpul Zakat

Pembentukan Unit Pengumpul Zakat ini bertujuan memberi kemudahan pengumpulan zakat, baik kemudahan bagi OPZ dalam

${ }^{37}$ Eri Sudewo, Manajemen., hal. 190-200.

${ }^{38}$ Ibid, hal. 201-204.

39 Departemen Agama RI Direktorat Jenderal Bimbingan Masyarakat Islam Direktorat Pemberdayaan Zakat, Standarisasi Manajemen Zakat, (Jakarta: tnp., 2007), hal. 91-94.

${ }^{40}$ Ibid, hal. 94-97. 
menjangkau para muzakki maupun kemudian bagi para muzakki untuk membayar zakatnya

2) Pembukaan Counter Penerimaan Zakat

Selain membuka Unit Pengumpul Zakat di berbagai tempat, OPZ dapat membuka kounter atau loket tempat pembayaran zakat di kantor atau sekretariat lembaga yang bersangkutan. Kantor yang dibuat harus representatif seperti layaknya loket lembaga keuangan profesional yang dilengkapi dengan ruang tunggu bagi muzakki yang akan membayar zakat, disediakan alat tulis dan penghitung seperlunya, disediakan tempat penyimpanan uang atau brangkas sebagai tempat pengamanan sementara sebelum disetor ke bank, ditunggu dan dilayani oleh tenaga-tenaga penerima zakat yang bersiap setiap saat sesuai jam pelayanan yang sudah ditentukan.

3) Pembukaan Rekening Bank

Suatu kemudahan lain bagi para muzakki untuk membayar zakat dan juga kemudahan bagi Organisasi Pengelola Zakat yang ada dalam menghimpun dana zakat dari para muzakki adalah membuka rekening pembayaran zakat, infak, dan shadaqah di bank dan dipublikasikan secara luas kepada masyarakat. Nomor rekening sedapat mungkin diupayakan nomor-nomor yang menarik dan mudah diingat. Sebaliknya nomor rekening untuk zakat dipisahkan dengan nomor rekening untuk infak dan shadaqah, agar memudahkan para muzakki untuk membayar zakat, infak, atau shadaqah.

4) Dapatkan dana pemukul gong, maksudnya adalah dapatkan satu donor yang sudah dikenal baik yang bisa memberikan sumbangan yang cukup untuk membiayai program pendayagunaan.

5) Dapatkan pendukung terkenal, tokoh-tokoh masyarakat, ulama panutan dapat dimanfaatkan untuk menarik dukungan ada suatu even tertentu kemudian. Momen khusus bisa dimanfaatkan untuk memperkenalkan OPZ pada khalayak ramai kemudian tokoh/panutan diminta untuk mempelopori pemberdayaan ZIS.

6) Buat Iklan (Janji)

Lebih baik mendapatkan dana besar meskipun menekan waktu lama dari pada dapatkan dalam waktu singkat tetapi kecil. Jadi perlu membuat semacam kartu lambing/pemberitahuan yang siap dibagikan setiap saat dibutuhkan

\section{b. Strategi Pendistribusian}

Salah satu fungsi zakat adalah fungsi sosial sebagai sarana saling berhubungan sesama manusia terutama antara orang kaya dan orang 
miskin, karena dana zakat dapat dimanfaatkan secara kreatif untuk mengatasi kemiskinan yang merupakan masalah sosial yang selalu ada dalam kehidupan masyarakat. Agar dana zakat yang disalurkan dapat berdayaguna dan berhasil guna, maka pemanfaatannya harus selektif untuk kebutuhan konsumtif atau produktif.

1) Konsumtif Tradisional

Zakat dibagikan kepada mustahiq secara langsung untuk kebutuhan konsumsi sehari-hari, seperti pembagian zakat fitrah berupa beras dan uang kepada fakir miskin setiap Idul Fitri atau pembagian zakat maal secara langsung oleh para muzakki yang sangat membutuhkan karena ketiadaan pangan atau karena mengalami musibah. Pola ini merupakan program jangja pendek dalam mengatasi permasalahan umat.

2) Konsumtif Kreatif

Zakat yang diwujudkan dalam bentuk barang konsumtif dan digunakan untuk orang miskin dalam mengatasi permasalahan sosial dan ekonomi yang dihadapinya. Bantuan tersebut antara lain berupa alat sekolah dan beasisa untuk para pelajar, bantuan sarana ibadah seperti sarung dan mukena, bantuan alat pertanian seperti cangkul untuk petani, gerobak jualan untuk pedagang kecil, dan sebagainya.

3) Produktif Konvensional

Zakat diberikan dalam bentuk barang produktif, di mana dengan menggunakan barang tersebut, para mustahiq dapat mencpiptakan suatu usaha, seperti pemberian bantuan ternak kambing, sapi perahan atau untuk membajak SAW.ah, alat pertukangan, mesin jahit, dan sebagainya.

4) Produktif Kreatif

Zakat yang diwujudkan dalam bentuk pemberian modal bergulir baik untuk permodalan proyek sosial seperti membangun sekolah, sarana kesehatan atau tempat ibadah bagi pengembangan usaha para pedagang atau pengusaha kecil.

\section{Aplikasi Kebijakan Dan Manajemen Zakat Pasca Kebijakan Disahkan}

\section{A. Kantor Pelayanan Pajak Pratama Yogyakarta}

Kebijakan Zakat sebagai pengurang penghasilan kena pajak diatur dalam Undang-undang Republik Indonesia Nomor 36 Tahun 2008 tentang Perubahan Keempat atas Undang-undang Nomor 7 Tahun 1983 tentang Pajak Penghasilan dan Keputusan Direktur Jendral Pajak dengan Nomor KEP-163/PJ/2003 mengenai 
Uzaifah: Manajemen Zakat...

Perlakuan Zakat atas Penghasilan dalam Penghitungan Penghasilan Kena Pajak Pajak Penghasilan.

KPP Pratama Yogyakarta yang melayani pembayaran pajak di wilayah kota Yogyakarta sudah menjalankan kebijakan "Zakat sebagai Pengurang Penghasilan Kena Pajak" sejak ditetapkannya Kep-DJP No. KEP-163/PJ/2003 sebagai panduan perlakuan zakat atas penghasilan dalam penghitungan penghasilan kena pajak penghasilan yang merupakan penjelas pasal 4 ayat (3) huruf a.1.Undang-undang Republik Indonesia Nomor 36 Tahun 2008 tentang Pajak Penghasilan dan yang sudah disahkan.

Kebijakan tersebut benar dilakukan dengan adanya item "Zakat atas Penghasilan yang menjadi Objek Pajak" dalam SPT tahunan PPh wajib pajak orang pribadi pada bagian A.6. (Penghasilan Neto Zakat Atas Penghasilan yang Menjadi Obyek Pajak).

Sedangkan sebagai bukti pembayaran zakat yang sudah dilakukan, pihak KPP mewajibkan wajib pajak melampirkan kuitansi pembayaran zakat dari OPZ tempat wajib pajak membayar zakat dimana OPZ tersebut adalah OPZ yang disahkan pendiriannya oleh pemerintah, dalam hal ini Departemen Agama Republik Indonesia. Persyaratan ini adalah sesuai dengan yang diatur dalam KepDJP No. KEP-163/PJ/2003 pasal 1 ayat (1), bahwa: "Zakat atas penghasilan yang nyata-nyata dibayarkan oleh wajib pajak...."

Pernyataan "nyata-nyata" adalah tuntutan adanya bukti pembayaran zakat oleh wajib pajak yang harus dapat diperlihatkan dan dilampirkan untuk dijadikan sebagai bukti. Lampiran tersebut bisa berupa bukti asli maupun fotokopi.

Selain itu, KPP juga mensyaratkan BAZ atau LAZ yang diakui sebagai OPZ yang berhak mengelola zakat, yaitu yang disahkan oleh pemerintah dalam hal ini Departemen Agama RI. Dapat dilihat dari Kep-DJP No. KEP-163/PJ/2003 pasal 1 ayat (1), bahwa:

Zakat atas penghasilan yang nyata-nyata dibayarkan oleh wajib pajak ... kepada badan amil zakat atau lembaga amil zakat yang dibentuk atau disahkan oleh pemerintah sesuai ketentuan Undang-undang Republik Indonesia Nomor 38 Tahun 1999 tentang Pengelolaan zakat.

Sedangkan di dalam BAB III Pasal 6 ayat 1 Undang-undang Republik Indonesia Nomor 38 Tahun 1999 tentang Pengelolaan zakat disebutkan: "Pengelolaan Zakat Dilakukan oleh BAZ yang Dibentuk oleh Pemerintah."

Berbagai kendala yang dihadapi oleh KPP dalam aplikasi kebijakan ini seperti telah disebutkan di bab sebelumnya antara lain:

a. Wajib pajak melakukan pembayaran zakat tidak melalui OPZ yang sudah disahkan oleh pemerintah, baik itu BAZ maupun LAZ melainkan dibayarkan secara langsung kepada mustahiq dan atau kepada lembaga 
amil zakat yang tidak disahkan pendiriannya oleh pemerintah, misalnya lembaga pengelola zakat masjid.

Perilaku tersebut mengakibatkan Wajib Pajak tidak bisa menjadikan zakat yang sudah dibayarkan untuk mengurangi penghasilan kena pajak.

Kendala seperti ini tidak perlu dihadapi manakala pemerintah menjadikan pengelolaan zakat adalah wajib oleh OPZ yang disahkan oleh pemerintah.

b. Keengganan sebagian wajib pajak mencantumkan jumlah zakat yang sudah dikeluarkan.

Hal tersebut dikarenakan zakat yang dikeluarkan adalah dari seluruh penghasilan yang dia peroleh. Sedangkan, adanya rasa enggan membayar pajak menyebabkan Wajib Pajak cenderung melaporkan hanya sebagian penghasilan yang dia peroleh dengan pertimbangan pajak yang akan dibayarkan adalah kecil.

Kedudukan zakat yang pertanggungjawabannya langsung kepada Allah SWT. menjadikan Wajib Pajak lebih bersikap jujur akan penghasilan yang diperolehnya. Namun, karena pajak hanya sebagai kewajiban kepada negara, maka Wajib Pajak hanya merelakan sebagian penghasilan mereka untuk membayar pajak.

Perilaku tersebut juga merupakan wujud ketidakpercayaan wajib pajak akan pengelolaan pajak di Indonesia. Yang tak kalah penting juga, pajak juga dianggap tidak mendistribusikan kekayaan sebagaimana mestinya dalam Islam, yaitu pemerataan. ${ }^{41}$

Hal ini tidak perlu terjadi apabila pemerintah melakukan perbaikan citra pada masyarakat agar kepercayaan masyarakat akan manfaat pajak dapat kembali lagi, yaitu sebagai sumber dana publik penunjang peningkatan kesejahteraan negara.

\section{B. Badan Amil Zakat Infak Shadaqah Provinsi Daerah Istimewa Yogyakarta}

Bazis Propinsi DIY yang dukukuhkan menjadi Bazis Propinsi DIY berdasarkan keputusan Gubernur Kepala DIY No. 9/KPTS/1992 merupakan organisasi pengelolaan zakat yang sah. Sesuai dengan BAB III pasal 6 ayat (2).b. disebutkan bahwa: "Pembentukan Badan Amil Zakat Daerah Propinsi oleh Gubernur Atas Usul Kepala Kantor Wilayah Departemen Agama Propinsi."

Sejak disahkannya Undang-undang Republik Indonesia Nomor 38 Tahun 1999 tentang Pengelolaan Zakat, organisasi pengelola zakat yang memenuhi ketentuan undang-undang secara langsung menerapkan amanat undang-undang

${ }^{41}$ Gusfahmi, Mencari Sinergi Pajak dan Zakat, diedit dalam Anonim, Majalah Ekonomi dan Bisnis Syari'ah Sharing, edisi 28 Thn III April 2009, (Jakarta: Griya Cahya, 2009), hal. 28. 
secara utuh, termasuk kebijakan "Zakat sebagai Pengurang Penghasilan Kena Pajak" sebagaimana yang dibunyikan pada pasal 14 ayat (3) bahwa:

Zakat yang telah dibayarkan kepada BAZ atau LAZ dikurangkan dari laba/pendapatan sisa kena pajak dari Wajib Pajak yang bersangkutan sesuai dengan peraturan perundang-undangan yang berlaku.

Dalam hal kebijakan ini, Bazis Propinsi DIY hanya memiliki wewenang sebatas mengeluarkan bukti pembayaran zakat muzakki. Namun, walaupun KPP menerima bukti pembayaran zakat yang dikeluarkan Bazis Propinsi DIY sebagai bukti pembayaran zakat yang sah, bukti pembayaran yang dikeluarkan oleh Bazis Propinsi DIY belum memenuhi ketentuan KPP sebagaimana diatur dalam Kep-DJP No. KEP-163/PJ/2003 pasal 4 ayat (2) yaitu:

a. Nama lengkap Wajib Pajak;

b. Alamat jelas Wajib Pajak;

c. Nomor Pokok Wajib Pajak (NPWP);

d. Jenis penghasilan yang dibayar zakatnya;

e. Sumber/jenis penghasilan dan bulan/tahun perolehannya;

f. Besarnya penghasilan;

Sebagaimana yang tercantum dalam bukti penerimaan kas tunai di Bazis Propinsi DIY, hanya mencantumkan:

a. Nama lengkap Wajib Pajak;

b. Alamat jelas Wajib Pajak;

c. Nomor Pokok Wajib Pajak (NPWP);

d. Jenis penghasilan yang dibayar zakatnya;

Isian tersebut masihlah kurang, karena masih ada dua informasi lagi guna melengkapi ketentuan dari KPP, yaitu:

a. Sumber/jenis penghasilan dan bulan/tahun perolehannya;

b. Besarnya penghasilan;

Peran Bazis Propinsi DIY hanya sampai mengeluarkan bukti penerimaan kas tunai zakat dari muzakki. Persoalan apakah muzakki akan menjadikannya bukti pembayaran zakat tidaklah dipantau ataupun dikawal oleh Bazis Proponsi DIY.

Ini adalah sebuah persoalan, di mana muzakki kehilangan kesempatan untuk meringankan beban dualisme pajak dan zakat. Namun, Bazis Propinsi DIY pun tidak bisa berbuat lebih selain memberikan sosialisasi secara langsung kepada muzakki.

Sosialisasi memang menjadi hal yang sangat penting. Namun, sosialisasi kebijakan ini masih belum dilakukan oleh Bazis DIY. Selain masalah dana, program kerja terkait sosialisasi kebijakan ini masih belum ada. Berdasarkan raker BAZ Propinsi DIY tanggal 16 Mei 2007, program sosialisasi hanya sebagas sosialisasi kewajiban zakat dan anjuran infak shadaqah baik melalui diskusi, seminar di media cetak maupun elektronik. Sosialisasi semacam ini masih belum cukup. Karena, 
terkait optimalisasi kebijakan, diperlukan sosialisasi khusus kepada muzakki tentang teknis pelaksanaan sampai dengan selesainya kegiatan pembayaran pajak di kantor pelayanan pajak.

\section{Manajemen Zakat Badan Amil Zakat Infak Shadaqah Provinsi Daerah Istimewa Yogyakarta}

\section{a. Manajemen Penghimpunan Dana Zakat}

Melalui kegiatan penghimpunan dana zakat yang dilakukan dengan dua cara, yaitu penerimaan dana ZIS melalui bank dan penerimaan dana ZIS secara langsung, terjadi tren penurunan dana zakat yang terhimpun.

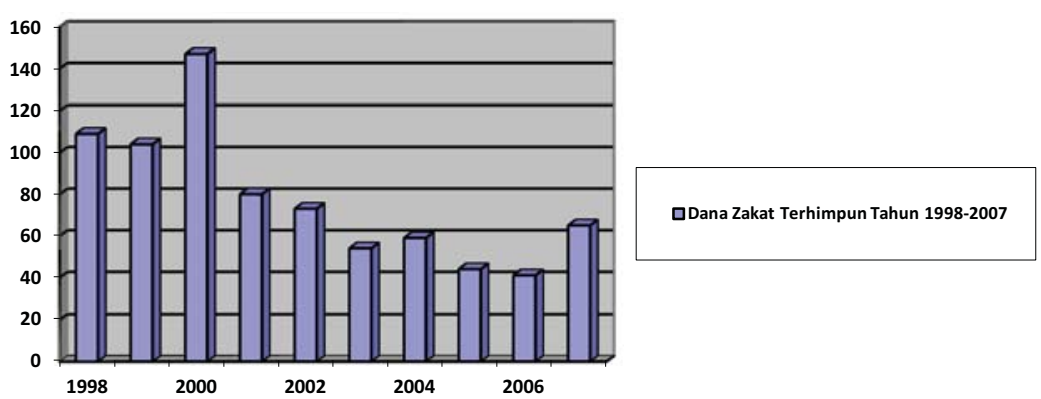

Gambar 4.1 : Dana Zakat Terhimpun Tahun 1998 - 2007

Sumber : Data diolah dari artikel Ahmad Muhsin Kamaludiningrat, Pemberdayaan Zakat Profesi Menuju Masyarakat Madani Sejabtera, disusun dan disampaikan dalam Workshop Pemberdayaan Zakat Profesi, hal. 18.

Turunnya jumlah dana zakat yang terhimpun sejak diberlakukannya kebijakan "Zakat sebagai Pengurang Penghasilan Kena Pajak" pada tahun 2003 semata-mata bukan karena kebijakan ini yang menjadi penyebabnya, melainkan karena adanya pemisahan pengelolaan zakat propinsi dan kabupaten-kabupaten yang ada di DIY pada tahun 2002 yang semula pengelolaan zakat tersentral di satu Bazis di DIY.

Kolektifitas zakat yang semula tersentral di satu Bazda, kini terpecah menjadi enam, yaitu:

1. Bazis Propinsi DIY

2. Bazis Kabupaten Sleman

3. Bazis Kabupaten Kulon Progo

4. Bazis Kabupaten Bantul

5. Bazis Kabupaten Kota Yogyakarta

6. Bazis Kabupaten Gunung Kidul 
Pemecahan pengelolaan zakat tersebut menjadikan jumlah zakat yang terhimpun di Bazis Provinsi jumlahnya menurun, karena sumber utama dari dana zakat yang berasal dari Pegawai Negeri Sipil menjadi terbagi pula sesuai dengan cakupan wilayahnya.

Walaupun pemisahan pengelolaan zakat di DIY tidak tersentralisasi lagi yang menyebabkan dana zakat masukpun menjadi berkurang, namun ada beberapa hal yang harus diperhatikan organisasi pengelola zakat dalam mengelola penghimpunan zakat.

Menurut Eri Sudewo, yang perlu diperhatikan dalam penggalangan dana di organisasi pengelola zakat adalah: ${ }^{42}$

a. Sumber dana yang berasal dari perorangan dan badan.

b. Sentuhan kepada donatur untuk membayar zakat di OPZ.

Beberapa kegiatan yang dilakukan dalam usaha penggalangan dana adalah dengan melakukan kampanye, menjalin kerjasama program, melakukan seminar dan diskusi, dan pemanfaatan rekening bank. Sedangkan layanan donatur dapat dilakukan dengan mendata donatur dengan baik, menerima keluhan-keluhan donatur ataupun pihak lain dan menindaklanjutinya. ${ }^{43}$

Bazis Propinsi DIY sudah melakukan beberapa dari manajemen pengumpulan zakat yang dikonsepkan oleh Eri Sudewo. Namun, usaha penggalangan dana belum membidik optimalisasi pemanfaatan kebijakan oleh muzakki. Hal ini bisa dilihat dari sosialisasi yang hanya yang hanya menekankan kewajiban zakat dan anjuran infak shadaqah dalam diskusi terbatas ataupun seminar melalui berbagai media. Diskusi ilmiah sebaiknya dikemas dengan tujuan sosialisasi kebijakan dan berbagai aturan terkait sehingga muzakki akan lebih sadar membayar zakat di OPZ.

Berdasarkan hasil wawancara dengan staf Bazis Propinsi DIY, program kerjasama Bazis Propinsi DIY hanya dilakukan dengan komponen masyarakat terkait yang belum bersenggolan sama sekali dengan kantor pelayanan pajak. Padahal kerjasama dua lembaga ini sangat besar manfaatnya dalam optimalisasi kebijakan. Kerjasama bisa dilakukan dengan membuka kounter pembayaran zakat/pajak di kantor zakat/pajak, sehingga pembayaran zakat dan pajak bisa lebih terkelola dengan baik dan mengoptimalkan dari sisi pemasukan masing-masing kantor.

Lain lagi yang dinyatakan oleh Didin Hafiduddin, bahwa pajak dan zakat harus lebih bersinergi. Salah satu poin penting untuk optimalisasi penghapusan dualisme pajak dan zakat adalah dengan melakukan revisi

${ }^{42}$ Eri Sudewo, Manajemen Zakat: Tinggalkan 15 Tradisi, Terapkan 4 Prinsip Dasar, (Jakarta: Institute Manajemen Zakat, 2004), hal. 190.

${ }^{43} \mathrm{Ibid}$, hal. 190-204. 
Undang-undang zakat, bahwa zakat adalah sebagai pengurang pajak, bukan hanya pengurang penghasilan. ${ }^{44}$

\section{b. Manajemen Penyaluran Dana Zakat}

Dengan tren menurun yang ditunjukan dari dana zakat yang masuk di Bazis Propinsi DIY menjadikan penyaluran zakatpun mengalami tren menurun dari segi jumlah.

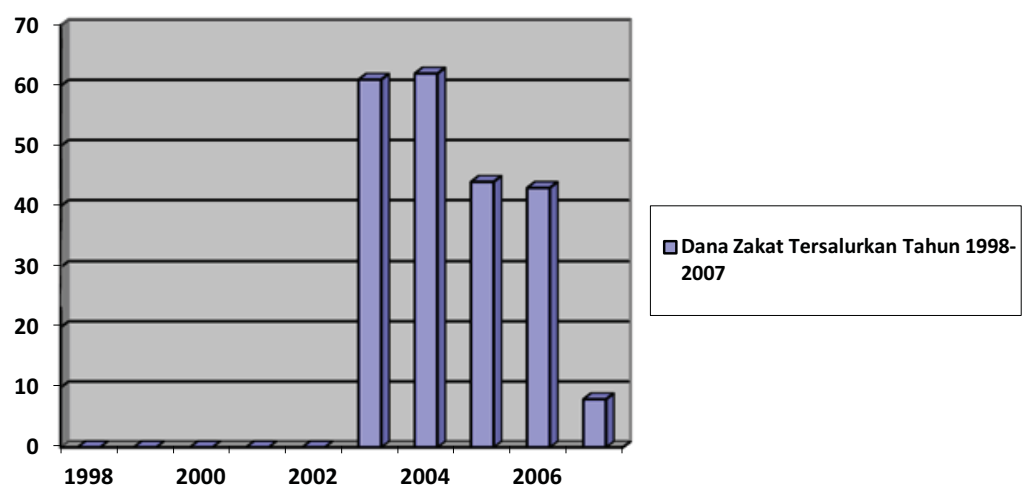

Gambar 4.2 : Dana Zakat Tersalurkan Tahun 1998 - 2007

Sumber : Data diolah dari laporan daftar permohonan bantuan pada Bazis Propinsi DIY.

Tujuan pengelolaan zakat yang ingin mengatasi masalah sosial kemasyarakatan berujung dari pendistribusian dana zakat terkumpul.

Dengan kebijakan "Zakat sebagai Pengurang Penghasilan Kena Pajak" yang sudah diaplikasikan pelaksanaannya oleh dua lembaga terkait, yaitu OPZ dan KPP, manajemen distribusi dana zakat di Bazis tidak mengalami perubahan.

Stagnasi tersebut dikarenakan selain penurunan dana zakat yang terhimpun di organisasi pengelola zakat juga karena cakupan distribusi sudah diatur oleh al-Qur'an dan hadis.

Penyaluran dana zakat yang dilakukan oleh organisasi pengelola zakat berjalan seperti manajemen penyaluran dana zakat sebelum disahkannya kebijakan "Zakat sebagai Pengurang Penghasilan Kena Pajak", yaitu:

a. Penyaluran yang Terencana, bantuan jenis ini misalnya:

1) Bantuan pembangunan masjid dan badan sosial lainnya.

${ }^{44}$ Didin Hafiduddin, "Zakat sebagai Pengurang Pajak", dalam Majalah Ekonomi dan Bisnis Syari'ah Sharing, edisi 28 Thn III April 2009, hal. 29. 
2) Pendidikan/beasiswa

3) Bantuan kepada pegawai instansi

4) Bantuan modal usaha

5) Pengembangan SDM

b. Penyaluran mendadak

Bantuan jenis ini diberikan kepada musafir, mu'allaf, dan bantuanbantuan lain yang mendadak sifatnya misalnya untuk orang sakit. Jenis bantuan ini dibiayai dengan melakukan penarikan tunai di BMT Mitra Nugraha yang dilakukan oleh staf Bazis Propinsi DIY sesuai kebutuhan.

\section{Penutup}

Kebijakan "Zakat sebagai Pengurang Penghasilan Kena Pajak" sebagaimana yang diamanatkan dalam pasal 14 ayat (3) Undang-undang Republik Indonesia Nomor 38 Tahun 1999 tentang Pengelolaan Zakat dan pasal 4 ayat (3) huruf a.1. dalam Undang-undang Republik Indonesia Nomor 36 Tahun 2008 tentang Perubahan Keempat atas Undang-undang Nomor 7 Tahun 1983 tentang Pajak Penghasilan, sudah diaplikasikan oleh Bazis Provinsi DIY dan KPP Pratama Yogyakarta. Aplikasi tersebut sudah sesuai dengan aturan yang berlaku di dalam Undang-undang dan kebijakan terkait.

Manajemen zakat Bazis Propinsi DIY, yaitu manajemen pengumpulan dan manajemen penyaluran dana zakat, pasca pengesahan kebijakan "Zakat sebagai Pengurang Penghasilan Kena Pajak" tidak mengalami perubahan. Namun, perubahan terjadi pada kuantitas dana zakat yang terkumpul dan terdistribusi melalui Bazis Propinsi DIY. Dana zakat terkumpul mengalami penurunan, dimana penurunan tersebut tidak terkait pada pengesahan dan pengaplikasian kebijakan "Zakat sebagai Pengurang Penghasilan Kena Pajak", namun dikarenakan pembagian wilayah pengelolaan zakat di Daerah Istimewa Yogyakarta yang semula hanya dikelola oleh satu Badan Amil Zakat menjadi dikelola oleh enam Badan Amil Zakat yang tersebar merata di wilayah Daerah Istimewa Yogyakarta.

Organisasi Pengelola Zakat harus lebih agresif lagi dalam mensosialisasikan kebijakan "Zakat sebagai Pengurang Penghasilan Kena Pajak" agar muzakki mendapatkan informasi yang utuh sehingga dapat memanfaatkan kebijakan ini dengan maksimal. Pemerintah sebagai regulator sebaiknya membuat peraturan mengenai hubungan kerjasama yang mungkin untuk dijalin antara Organisasi Pengelola Zakat dengan Kantor Pelayanan Pajak agar pelaksanaan kebijakan "Zakat sebagai Pengurang Penghasilan Kena Pajak" dapat lebih optimal terutama dalam menuju tujuan utamanya yaitu minimalisasi beban ganda muzakki warga negara. Zakat yang dimaksud dalam kebijakan ini adalah zakat penghasilan. Oleh karena itu, diharapkan pemerintah membuat peraturan perundang-undangan dimana tidak hanya zakat penghasilan yang diakui sebagai pengurang penghasilan kena pajak. Perlunya sosialisasi khusus mengenai 
kebijakan ini yang harus dilakukan oleh pemerintah agar tujuan dibuatnya kebijakan ini bisa terwujud.

\section{DAFTAR PUSTAKA}

Al-Ba'Iy, Abdul Al-Hamid Mahud. 2006. Ekonomi Zakat Sebuah Kajian Moneter dan Keuangan Syariah; Terjemahan oleh Muhammad Abqary Abdullah Karim, dari Iqtishaasiyaatu az-zakat wa'tibaaraatus siyaasah (1991). Jakarta: Rajawali Press.

Alamsyah, Cecep. 2001. "Potensi Zakat Perdagangan dan Problematikanya (Penelitian pada Pedagang Pasar Cikurubuk Tasikmalaya)”. Tesis. Tidak Dipublikasikan. Yogyakarta: MSI UII.

Ali, Nuruddin Mhd. 2006. Zakat sebagai Instrumen dalam Kebijakan Fiskal. Jakarta: PT. RajaGrafindo Persada.

Basyir, Ahmad Azhar. 1997. Hukum Zakat. Yogyakarta: Lukman Offset.

Dahlan, M. Rasna. 2002. "Konsep Zakat untuk Pemberdayaan Ekonomi Ummat dalam Perspektif Ekonomi Islam”. Tesis. Tidak Dipublikasikan. Yogyakarta: MSI UII.

Departemen Agama RI Direktorat Jendral Bimbingan Masyarakat Islam Direktorat Pemberdayaan Zakat. 2007. Standarisasi Manajemen Zakat. Jakarta: Departemen Agama RI Direktorat Jendral Bimbingan Masyarakat Islam Direktorat Pemberdayaan Zakat.

Djuanda, Gustian dkk. 2006. Pelaporan Zakat Pengurang Pajak Penghasilan. Jakarta: PT. RajaGrafindo Persada.

Gusfahmi. 2007. Pajak Menurut Syariah. Jakarta: PT. Raja Grafindo Persada.

Hadi, Syamsul. 2006. Metodologi Penelitian Kuantitatif untuk Akuntansi dan Keuangan. Yogyakarta: Ekonisia.

Hafidhuddin, Didin. 2000. Tentang Zakat Infak Sedekah. Jakarta: Gema Insani Press.

Hariwijaya, Muhammad dan Bisri M. Djaelani. 2006. Teknik Menulis Skripsi \& Thesis. Yogyakarta: Zenith Publisher.

Hardiansyah. 2002. "Manajemen Strategis Pengumpulan Zakat, Infaq, dan Shadaqah pada Era Otonomi Daerah (Studi Kasus pada BAZIS DIY)". Tesis. Tidak Dipublikasikan. Yogyakarta: UGM.

Harul, Romansyah. 2002. "Undang-Undang Zakat sebagai Perangkat Optimalisasi Kegiatan BAZ Kota Samarinda Kalimantan Timur”. Tesis. Tidak Dipublikasikan. Yogyakarta: MSI UII.

Ismanto, Kuat. 2009. Manajemen Syariah: Implementasi TQM dalam Lembaga Keuangan Syariah. Yogyakarta: Pustaka Pelajar.

Jusmaliani dkk. 2005. Kebijakan Ekonomi dalam Islam. Yogyakarta: Kreasi Wacana. 
Uzaifah: Manajemen Zakat...

Kuncoro, Mudrajat. 2004. Metode Kuantitatif: Teori dan Aplikasi untuk Bisnis dan Ekonomi, Edisi 2. Yogyakarta: APP UMP YKPN.

Mufraini, Arif. 2006. Akuntansi dan Manajemen Islam: Mengkomunikasikan Kesadaran dan Membangun Jaringan). Jakarta: Kencana.

Mughniyah, Muhammad Jawad. 2006. Fiqih Lima Mazhab; Terjemahan oleh Masykur dkk., dari Al-Fiqh 'Ala Al-Madzahib Al-Khamsah (__ _ Jakarta: Lentera.

Muhammad. 2002. Zakat Profesi: Wacana Pemikiran dalam Fikih Kontemporer. Jakarta: Salemba Diniyah.

Muhammad dan Ridwan Mas'ud. 2005. Zakat dan Kemiskinan Instrumen Pemberdayaan Ekonomi Umat. Yogyakarta: UII Press.

Mulyana, Deddy. 2004. Metodologi Penelitian Kualitatif. Bandung: PT. Remaja Rosdakarya.

Nazir, Habib dan Muhammad Nasahuddin. 2008. Ensiklopedi Ekonomi dan Perbankan Syariah. Bandung: Kafa Publishing.

Qardawi, Yusuf. 2006. Hukum Zakat; Terjemahan oleh Salman Harun dkk., dari Fiqhuz-zakat (1973). Jakarta: PT. Pustaka Litera AntarNusa.

Rahman, Afzalur. 1996. Doktrin Ekonomi Islam, Jilid 3; Terjemahan oleh Soeroyo dan Nastangin, dari Economic Doctrines of Islam (1992). Yogyakarta: PT. Dana Bhakti Wakaf.

Rahmaniar. 2002. "Studi tentang Pengelolaan Zakat di Kecamatan Pahandut Palangkaraya”. Tesis. Tidak Dipublikasikan. Yogyakarta: MSI UII.

Sudarsono, Heri dan Hendi Yogi Prabowo. 2004. Istilah-Istilah Bank dan Lembaga Keuangan Syariah. Yogyakarta: UII Press.

Sudewo, Eri. 2004. Manajemen Zakat: Tinggalkan 15 Tradisi, Terapkan 4 Prinsip Dasar. Jakarta: Institute Manajemen Zakat. . 2008. Politik ZISWAF: Kumpulan Esei. Tangerang: CID-Dompet Dhuafa.

Suharto, Ugi. 2004. Keuangan Publik Islam: Reinterpretasi Zakat dan Pajak. Yogyakarta: Pusat Studi Zakat.

Supardi. 2005. Metodologi Penelitian Ekonomi \& Bisnis. Yogyakarta: UII Press.

Suprayogo, Imam dan Tobroni. 2003. Metodologi Penelitian Sosial-Agama. Bandung: PT Remaja Rosdakarya.

Wibisono, Yusuf. 2005. Metode Statistik. Yogyakarta: Gadjah Mada University Press.

Yunus, Muhammad. 2008. Bank Kaum Miskin: Kisah Yunus dan Grameen Bank Memerangi Kemiskinan). Jakarta: Batu Merah.

\section{Peraturan Pendukung}


Keputusan Direktur Jendral Pajak dengan Nomor KEP-163/PJ/2003 mengenai Perlakuan Zakat atas Penghasilan dalam Penghitungan Penghasilan Kena Pajak Pajak Penghasilan.

Keputusan Meteri Agama Republik Indonesia Nomor 581 Tahun 1999 tentang Pelaksanaan Undang-undang Nomor 38 Tahun 1999 tentang Pengelolaan Zakat.

Undang-undang Republik Indonesia Nomor 36 Tahun 2008 tentang Perubahan Keempat atas Undang-undang Nomor 7 Tahun 1983 tentang Pajak Penghasilan.

Undang-undang Republik Indonesia Nomor 38 Tahun 1999 tentang Pengelolaan Zakat.

\section{Internet}

Abidin, Said Zainal. "Kebijakan Publik". Ditulis dalam Pakde Sofa. (2008). "Kajian Ilmu Kebijakan dan Pengertian Kebijakan”. Dikutip dari http://massofa.wordpress.com/2008/11/13/kajian-ilmu-kebijakan-danpengertian-kebijakan/accecced 30 April 2009.

Al-Jufri, Salim Segaff dan Didin Hafidhuddin. (2001). "Peran Amilin (Pengelola) Zakat: Sebuah Model Pengelolaan ZIS”. Dikutip dari http://www.pkpu.or.id/z001.php?id=18/accessed 26 Mei 2009.

Arief, Moch.. (2009) "Antara Zakat \& Pajak". Dikutip dari http://dsniamanah.or.id/web/content/view/110/1/accessed 26 Mei 2009.

(2009). "Prinsip Pengelolaan Zakat". Dikuti dari http://dsniamanah.or.id/web/content/view/86/71/accessed 26 Mei 2009.

Arifah, Siti. "Konstitusi Negara Berbicara 'Zakat Mengurang Penghasilan Kena Pajak”. Dikutip dari http://www.pkpu.or.id/artikel.php?id=20\&no=15/accessed 1 Februari 2008 .

Permono, Hadi. "Menghitung Zakat dan Pajak". Dikutip dari http://www.bazjatim.or.id/zakat4.php/accessed 1 Februari 2008.

Permono, Hadi. "Zakat dan Pajak". Dikutip dari http://www.pnm.co.id/content.asp?id=247\&mid=77/accessed 1 Februari 2008.

Redaksi. (2009). "Profesi Amil Zakat Perlukah?”. Dikutip dari http://dsniamanah.or.id/web/content/view/132/71/accessed 26 Mei 2009.

Redaksi. (2009). “Teori Manajemen Zakat dan Teori Pengelolaan Zakat”. Dikutip dari http://www.Imi-amilzakat.com/?mod=zakatkonsul\&id=17/accessed 20 Mei $\underline{2009}$. 
Uzaifah: Manajemen Zakat...

Redaksi. “Zakat=Pajak?”. Dikutip dari http://pkpu.or.id/z.php?t=a\&id=11/accessed 1 Februari 2008.

Redaksi. (2009). "Zakat Accounting \& Finance Managemen". Dikutip dari http://dsniamanah.or.id/web/content/view/97/71/accessed 26 Mei 2009.

Republika Newsroom. (2009). "Pemerintah Usulkan Ancaman Hukuman bagi Muzakki yang tak Berzakat". Dikutip dari http://www.republika.co.id/berita/33544/Pemerintah Usulkan Ancaman Hu kuman bagi Muzakki yang tak Berzakat/accessed 29 Mei 2009.

Suharsono, M.. (2004). "Globalisasi dan Modernisasi Zakat: Dulu dan Sekarang”. Dikutip dari http://www.pkpu.or.id/artikel.php?id=19\&no=15/accessed 26 Mei 2009. 